\title{
Case Report \\ Dentinogenic Ghost Cell Tumor of the Peripheral Variant Mimicking Epulis
}

\author{
Uddipan Kumar, ${ }^{1}$ Hitesh Vij, ${ }^{2}$ Ruchieka Vij, ${ }^{2}$ Jitin Kharbanda, ${ }^{3}$ IN Aparna, ${ }^{4}$ \\ and Raghu Radhakrishnan ${ }^{5}$ \\ ${ }^{1}$ Department of Oral Pathology and Microbiology, Hazaribag College of Dental Sciences and Hospital, Hazaribag 825 301, \\ Jharkhand, India \\ ${ }^{2}$ Department of Oral Pathology, Institute of Dental Studies and Technologies, Modinagar, Uttar Pradesh 201 201, India \\ ${ }^{3}$ Department of Oral Pathology, Shree Bankey Bihari Dental College, Masuri, Ghaziabad 201 302, India \\ ${ }^{4}$ Department of Prosthodontics, Manipal College of Dental Sciences, Manipal University, Manipal 576 104, India \\ ${ }^{5}$ Department of Oral Pathology and Microbiology, Manipal College of Dental Sciences, Manipal University, Manipal 576 104, India
}

Correspondence should be addressed to Raghu Radhakrishnan, raghu.radhakrishnan@gmail.com

Received 29 August 2010; Accepted 10 October 2010

Academic Editor: Ahmad Waseem

Copyright ( 2010 Uddipan Kumar et al. This is an open access article distributed under the Creative Commons Attribution License, which permits unrestricted use, distribution, and reproduction in any medium, provided the original work is properly cited.

\begin{abstract}
Dentinogenic ghost cell tumor (DGCT) is an uncommon locally invasive odontogenic tumor regarded by many as a variant of calcifying odontogenic cyst. The peripheral variant of this clinical rarity appears as a well-circumscribed mass mimicking a nonspecific gingival enlargement. Microscopic appearance of odontogenic epithelium admixed with focal areas of dentinoid formation and sheets of ghost cells giving the definitive diagnosis of dentinogenic ghost cell tumor imply that microscopic examination is compulsory for any gingival mass. Van Gieson histochemical stain further confirmed the nature of dentinoidlike material. A complete workup of a case of peripheral dentinogenic ghost cell tumor is presented in this paper and the current concept as well as the appraisal of literature is presented.
\end{abstract}

\section{Introduction}

Calcifying odontogenic cyst (COC) is a unique jaw lesion, first recognized as a distinct entity by Gorlin et al. [1] and hence the eponym Gorlin cyst. Praetorius et al. [2] classified them into the cystic type (Type I) and the solid type (Type II). The solid variant of COC (Type II) is rare and is designated as dentinogenic ghost cell tumor (DGCT), although the first description of the solid variant was given by Fejerskov and Krogh as calcifying ghost cell odontogenic tumor [3]. DGCT is characterized microscopically by ameloblastoma-like odontogenic epithelial proliferation, presence of ghost cells, and dentinoid-like material [4]. Due to its diverse histological picture, several terms have been used by different authors to describe this lesion such as dentinogenic ghost cell tumor [2], calcifying ghost cell odontogenic tumor [3], keratinizing ameloblastoma [5], cystic calcifying odontogenic tumor [6], peripheral odontogenic tumor with ghost cell keratinization [7], denti- noameloblastoma [8], ameloblastic dentinoma [9], epithelial odontogenic ghost cell tumour [10], and odontogenic ghost cell tumor [11].

The term DGCT is commonly used, and the peripheral variant of this neoplastic entity is rare; only few reports with clinical, radiographic, and histologic documentation can be found in the English literature. A report of peripheral dentinogenic ghost cell tumor (PDGCT) and characterization of dentinoid material using Van Gieson special stain for the confirmation adds a new dimension to the diagnosis of DGCT.

\section{Case Report}

A 40-year-old male patient reported to the dental clinics at Manipal College of Dental Sciences, Manipal University, with a complaint of missing teeth. Clinical examination disclosed a swelling measuring about $5 \mathrm{~mm}$ in diameter in the region 


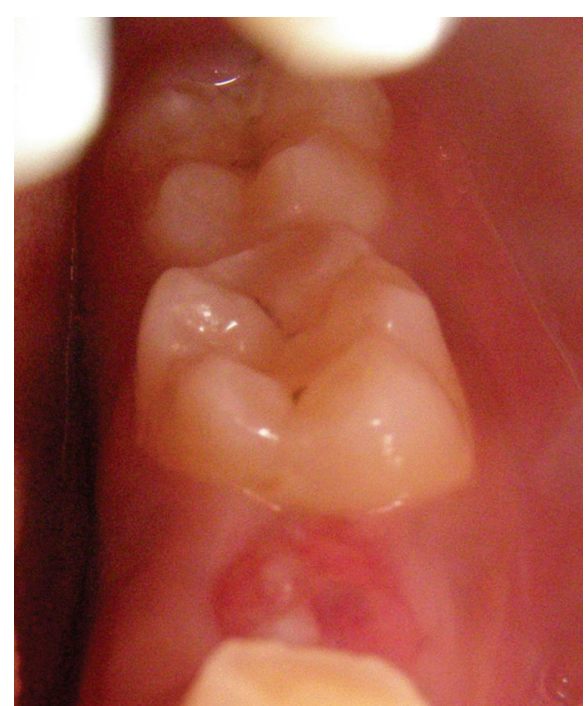

FIgURE 1: A nontender, persistent swelling in the region of lower left posterior region.

of lower left premolars which was non tender, and the over lying mucosa was normal in color. Clinically, a provisional diagnosis of epulis was made (Figure 1). The lesion was excised under local anesthesia, and the tissue was submitted for histopathological examination. Six months of followup examination did not show any signs of recurrence.

Histological examination revealed a solid well-circumscribed, encapsulated soft tissue mass surrounded by a dense fibrous connective tissue covered by stratified squamous epithelium (Figure 2). The tumor mass revealed islands of odontogenic epithelium resembling follicles of ameloblastoma, consisting of columnar cells enclosing stellate reticulum like cells (Figure 3 ). These elements were associated with numerous pale, eosinophilic ghost cells with granular eosinophilic cytoplasm and faint nuclear outline (Figure 4). Few multinucleated giant cells of foreign body type were evident at the periphery of the ghost cells in the connective tissue stroma. Irregular foci of tissue resembling dentin were observed surrounding the odontogenic epithelial islands, and these areas were atubular and at places showed cellular inclusions (Figure 5). Van Gieson special stain was carried out to examine the nature of the dentinoid-like material (Figure 6). The characteristic microscopic features and the confirmation of dentinoid-like material by special stain contributed to the diagnosis of dentinogenic ghost cell tumor of the peripheral variant.

\section{Discussion}

DGCT is a distinct but a rare histological entity among odontogenic ghost cell lesions which have been recently classified into the simple cystic type or COC; cysts associated with odontogenic hamartomas or benign neoplasms; solid benign odontogenic neoplasm, which is same as COC but with dentinoid formation, the DGCT; malignant odontogenic neoplasm-ghost cell odontogenic carcinoma [8]. The

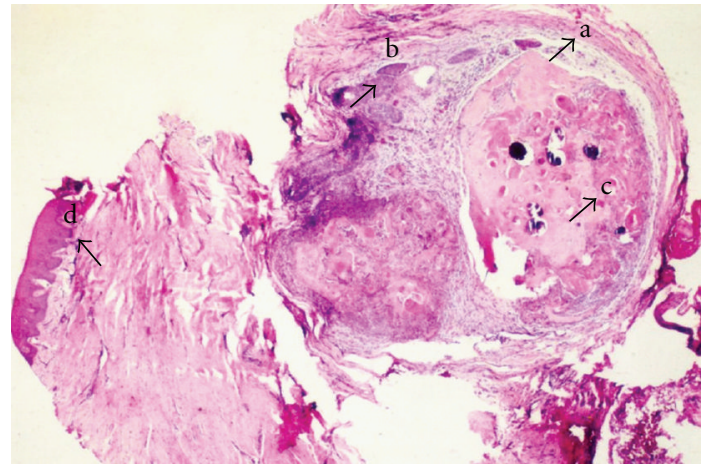

FIGURE 2: Solid wellcircumscribed encapsulated mass (a) showing ameloblastomatous islands of odontogenic epithelium (b) and ghost cells (c) with overlying epithelium (d) [Hematoxylin and Eosin, $\times 4$ ].

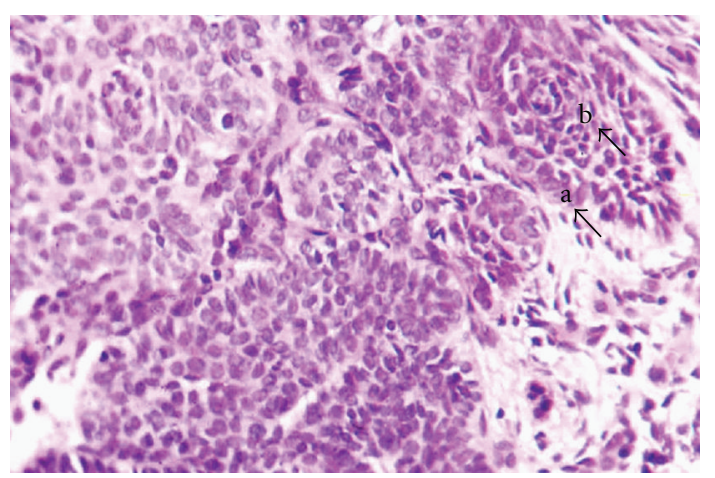

FIGURE 3: Ameloblastomatous island of odontogenic epithelium with columnar basal cells (a) enclosing stellate reticulum like cells (b) [Hemataoxylin and Eosin, $\times 40]$.

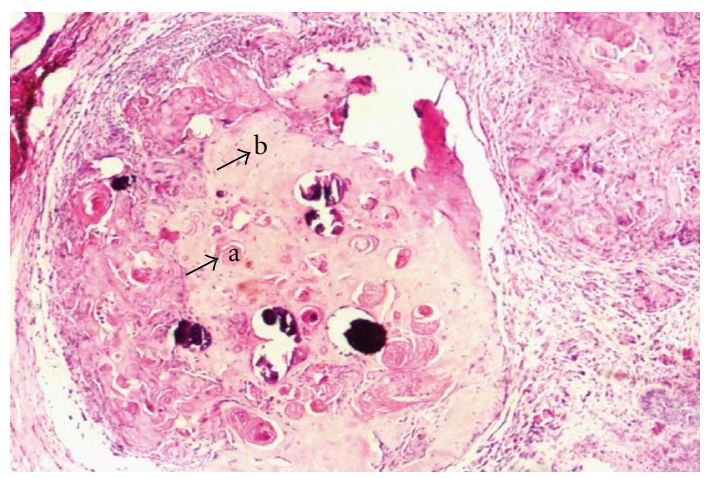

FIGURE 4: Ghost cells (a) and surrounding dentinoid-like material (b) [Hemataoxylin and Eosin, $\times 20$ ].

peripheral dentinogenic ghost cell tumor (PDGCT), though a distinct entity of odontogenic origin, is apparently rare. This rarity is due to the failure of its recognition as an isolated entity [12], and many of the cases of PDGCT have been mistakenly diagnosed as peripheral ameloblastoma [13]. 
TABLE 1: Reported cases of peripheral dentinogenic ghost cell tumor.

\begin{tabular}{|c|c|c|c|c|c|}
\hline Sl no. & Reference & $\begin{array}{l}\text { No. of } \\
\text { cases }\end{array}$ & $\begin{array}{l}\text { Age in } \\
\text { years/sex }\end{array}$ & Site & Radiographic features \\
\hline 1 & Abrams and Howell [14] & 1 & $13 / \mathrm{M}$ & Extraosseous & No significant findings \\
\hline 2 & Sauk $[15]$ & 1 & $67 / \mathrm{F}$ & Extraosseous & No radiographic changes \\
\hline \multirow[t]{2}{*}{3} & \multirow{2}{*}{ Praetorius et al. [2] } & \multirow[t]{2}{*}{2} & $52 / \mathrm{M}$ & $\begin{array}{l}\text { Maxillary left lateral incisor } \\
\text { and canine region }\end{array}$ & Slight erosion of underlying bone \\
\hline & & & $41 / \mathrm{F}$ & Mandibular anterior region & Slight erosion of underlying bone \\
\hline 4 & Hirshberg et al. [16] & 1 & $42 / \mathrm{M}$ & $\begin{array}{l}\text { Mandibular left premolar } \\
\text { region (lingual gingiva) }\end{array}$ & No bone involvement \\
\hline 5 & McClatchey et al. [17] & 1 & $57 / \mathrm{M}$ & Mandibular anterior region & No bone involvement \\
\hline \multirow{3}{*}{6} & \multirow{3}{*}{ Buchner et al. [12] } & \multirow{3}{*}{3} & $10 / \mathrm{M}$ & Mandibular central incisor & - \\
\hline & & & $53 / \mathrm{F}$ & Mandibular edentulous ridge & - \\
\hline & & & $92 / \mathrm{F}$ & $\begin{array}{l}\text { Mandibular edentulous } \\
\text { cuspid-premolar region }\end{array}$ & - \\
\hline 7 & Günhan et al. [18] & 1 & $71 / \mathrm{F}$ & Maxillary anterior region & Slight erosion of underlying bone \\
\hline 8 & Raubenheimer et al. [19] & 1 & $82 / \mathrm{M}$ & $\begin{array}{l}\text { Mandibular right alveolar } \\
\text { ridge (edentulous) }\end{array}$ & No bone involvement \\
\hline 9 & Castro et al. [20] & 1 & $83 / \mathrm{F}$ & $\begin{array}{l}\text { Anterior ridge of edentulous } \\
\text { mandible }\end{array}$ & Cup shaped resorption \\
\hline 10 & Wong et al. [9] & 1 & $71 / \mathrm{M}$ & Maxillary canine region & Slight erosion beneath the growth \\
\hline 11 & Iezzi et al. [21] & 1 & $43 / \mathrm{M}$ & Maxillary canine region & No bone involvement \\
\hline 12 & $\begin{array}{l}\text { Ledesma-Montes et al. } \\
\text { [22] }\end{array}$ & 1 & NS & NS & NS \\
\hline 13 & Candido et al. [23] & 1 & $45 / \mathrm{M}$ & Mandibular canine region & No bone involvement \\
\hline 14 & Our case & 1 & $40 / \mathrm{M}$ & Mandibular premolar area & - \\
\hline
\end{tabular}

NS: Not Specified.

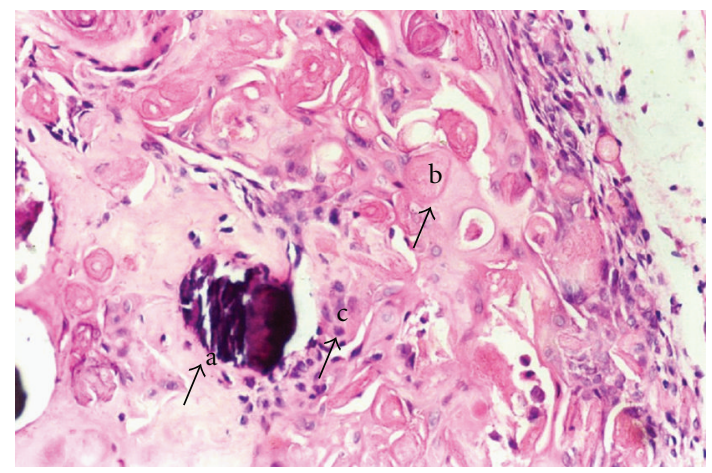

Figure 5: Irregular foci of dentine/osteo-dentine-like material (a) and calcifying ghost cells (b) and giant cells (c) [Hemataoxylin and Eosin, $\times 40]$.

The usual presentation of the peripheral variant is a nodular swelling on the edentulous alveolar mucosa of denture wearers, a feature that implicates trauma/irritation. This clinical presentation could lead to the provisional diagnosis of epulis as was true in our case as well. Due to the dearth of documented cases, it is difficult to typify the exact location, age, and gender distribution of PDGCT. However based on the existing literature it appears to be more common in the canine-premolar region, with a predilection for the elderly age group $[2,9,12,14-23]$ (Table 1). Hirshberg

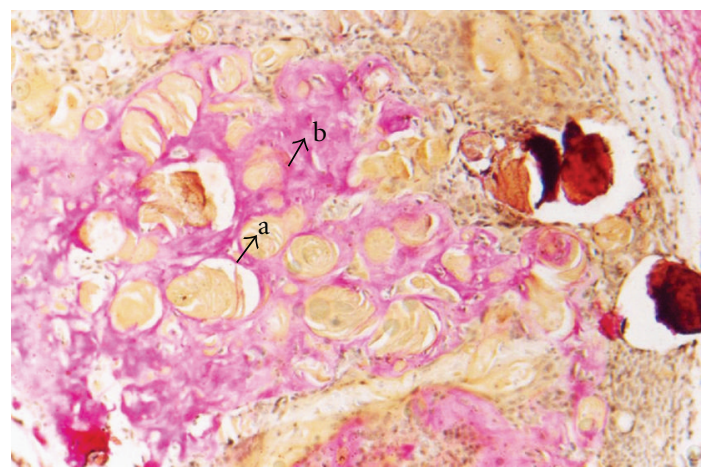

FIgURE 6: Van Gieson stains showing ghost cells staining yellow (a) and surrounding dentinoid-like material staining pink (b) [Van Gieson stain, $\times 40]$.

et al. [16] indicated that the tumor mainly affects the maxilla and occurs four times more commonly among men. Contrary to this, Hong et al. [24] reported that it mainly occurs in the mandibular edentulous mucosa without any sex predilection. This lesion seems to be less aggressive than its central counterpart with no recurrences reported after excision [12].

Based on this histological diversity, the origin of this lesion has been attributed to cell rests of Serres or the surface epithelium $[25,26]$. The tumor is mainly composed 
of ameloblastoma-like areas of odontogenic epithelial islands with varying amount of ghost cells showing keratinization and calcification. It may histologically show areas similar to or may be associated with odontogenic tumors like complex and compound odontomes, ameloblastic fibroodontoma, and so forth. Ghost cells are thought to be transformed odontogenic epithelial cells, the mechanism of whose transformation remains unknown [8]. In light microscope, they appear as enlarged, ovoid, or elliptoid epithelial cells, which are eosinophilic, usually with welldefined cell outlines but may be blurred giving them a fused appearance. Histochemically, they are positive for keratin giving a yellow fluorescence with Rhodamine B. Sometimes ghost cells may contain nuclear remnants in various stages of degeneration. The calcification which may occur in some of these ghost cells appear initially as fine powdery/coarse basophilic granules and later as small spherical bodies. Ultrastructural studies have shown that these calcifications represent dystrophic calcification [27].

Due to its biological behavior COC, and its variants are thought to resemble a benign odontogenic tumor rather than a cyst [6]. Previously, Abrams and Howell [14] have established that the term "cyst" does not imply in all instances as its clinical features, growth behavior, and recurrence potential are quite similar to those of ameloblastoma. It has also been emphasized that calcifications found in COC and CEOT are not a feature of ameloblastoma and the combined occurrence of COC with other odontogenic lesions could be due to the multipotentiality of odontogenic epithelium [4]. Further it is pointed out that this lesion in association with an odontoma may result due to differentiation and degeneration of odontogenic epithelium [14]. What appears as associated odontogenic tumor should be considered as an integral part of an entire lesion developing in the wall of COC [2].

In our case as well, the presence of keratinizing ghost cells and mineralization was an outstanding feature. The lesion did not exhibit any cystic areas, and its features were consistent with those of DGCT. The calcifications seen as dentoid, frequently described in connection with masses of ghost cells, were a characteristic finding of this lesion. These calcified areas were thought to represent juxtaepithelial osteoid formation by granulation tissue due to induction by ghost cells [14]. This view was however negated later as juxtaepithelial osteoid and dentinoid were observed in areas free of granulation tissue and ghost cells, as pointed out by Tajima et al. [28]. There are no reports or studies to clarify if this is an inductive effect or a metaplastic change in the connective tissue. In the present case as well, the calcified material was found either in areas where the ghost cells and connective tissue were in contact or in the connective tissue adjacent or below the basal cells, possibly due to the inductive effects of ghost cells/epithelial cells [29]. Van Gieson special stain illustrated the collagenous nature of the dentinoid-like material. The histological and histochemical attributes of the dentinoid-like calcification described in this peripheral odontogenic tumor best fitted with the diagnosis of Peripheral Dentinogenic Ghost Cell Tumor.
Conservative but aggressive local resection has been the treatment of choice with no recurrences found in any patient. However patients with a DGCT should remain in longterm follow-up [30]. Though numerous terminologies have been suggested for this entity, we propose that for a lesion with the above histological and histochemical characteristics, Peripheral Dentinogenic Ghost Cell Tumor best describes it and should be the most preferred designation.

\section{Abbreviations}

DGCT: Dentinogenic ghost cell tumor

COC: Calcifying odontogenic cyst

PDGCT: Peripheral dentinogenic ghost cell tumor.

\section{References}

[1] R. J. Gorlin, J. J. Pindborg, F. P. Clausen, and R. A. Vickers, "The calcifying odontogenic cyst-a possible analogue of the cutaneous calcifying epithelioma of Malherbe. An analysis of fifteen cases," Oral Surgery, Oral Medicine, Oral Pathology, vol. 15, no. 10, pp. 1235-1243, 1962.

[2] F. Praetorius, E. Hjorting-Hansen, R. J. Gorlin, and R. A. Vickers, "Calcifying odontogenic cyst. Range, variations and neoplastic potential," Acta Odontologica Scandinavica, vol. 39, no. 4, pp. 227-240, 1981.

[3] O. Fejerskov and J. Krogh, "The calcifying ghost cell odontogenic tumor-or the calcifying odontogenic cyst," Journal of Oral Pathology, vol. 1, no. 6, pp. 273-287, 1972.

[4] Y. Tajima, S. Yokose, E. Sakamoto, Y. Yamamoto, and N. Utsumi, "Ameloblastoma arising in calcifying odontogenic cyst: report of a case," Oral Surgery Oral Medicine and Oral Pathology, vol. 74, no. 6, pp. 776-779, 1992.

[5] S. N. Bhaskar, "Oral surgery-oral pathology conference no. 13, Walter Reed Army Medical Center," Oral Surgery, Oral Medicine, Oral Pathology, vol. 19, no. 6, pp. 796-807, 1965.

[6] P. D. Freedman, H. Lumerman, and J. K. Gee, "Calcifying odontogenic cyst. A review and analysis of seventy cases," Oral Surgery Oral Medicine and Oral Pathology, vol. 40, no. 1, pp. 93-106, 1975.

[7] J. C. Vuletin, M. P. Solomon, and L. P. Pertschuk, "Peripheral odontogenic tumor with ghost-cell keratinization. A histologic, fluorescent microscopic, and ultrastructural study," Oral Surgery Oral Medicine and Oral Pathology, vol. 45, no. 3, pp. 406-415, 1978.

[8] M. Shear and P. Speight, Cysts of the Oral and Maxillofacial Regions, Blackwell, Munksgaard, Danmark, 4th edition, 2007.

[9] Y. K. Wong, S. C. Chiu, S. W. Pang, and J. C. F. Cheng, "Peripheral dentinogenic ghost cell tumour presenting as a gingival mass," British Journal of Oral and Maxillofacial Surgery, vol. 42, no. 2, pp. 173-175, 2004.

[10] G. L. Ellis and B. M. Shmookler, "Aggressive (malignant?) epithelial odontogenic ghost cell tumor," Oral Surgery, Oral Medicine, Oral Pathology, vol. 61, no. 5, pp. 471-478, 1986.

[11] G. L. Ellis, "Odontogenic ghost cell tumor," Seminars in Diagnostic Pathology, vol. 16, no. 4, pp. 288-292, 1999.

[12] A. Buchner, P. W. Merrell, L. S. Hansen, and A. S. Leider, "Peripheral (extraosseous) calcifying odontogenic cyst. A review of forty-five cases," Oral Surgery Oral Medicine and Oral Pathology, vol. 72, no. 1, pp. 65-70, 1991. 
[13] T. Nagao, T. Nakajima, M. Fukushima, and T. Ishiki, "Alcifying odontogenic cyst: a survey of 23 cases in the Japanese literature," Journal of Maxillofacial Surgery, vol. 11, no. 4, pp. 174-179, 1983.

[14] A. M. Abrams and F. V. Howell, "The calcifying odontogenic cyst. Report of four cases," Oral Surgery, Oral Medicine, Oral Pathology, vol. 25, no. 4, pp. 594-606, 1968.

[15] J. J. Sauk Jr., "Calcifying and keratinizing odontogenic cyst," Journal of Oral Surgery, vol. 30, no. 12, pp. 893-897, 1972.

[16] A. Hirshberg, D. Dayan, and I. Horowitz, "Dentinogenic ghost cell tumor," International Journal of Oral and Maxillofacial Surgery, vol. 16, no. 5, pp. 620-625, 1987.

[17] K. D. McClatchey, J. C. Stewart, and B. D. Patterson, "Dentinogenic ghost cell tumor presenting as a gingival mass," Annals of dentistry, vol. 47, no. 1, pp. 31-32, 1988.

[18] O. Günhan, A. Mocan, C. Can, R. Kişnişci, A. Y. Aksu, and R. Finci, "Epithelial odontogenic ghost cell tumor: report of a peripheral solid variant and review of the literature," Annals of dentistry, vol. 50, no. 2, pp. 8-48, 1991.

[19] E. J. Raubenheimer, W. F. P. Van Heerden, F. Sitzmann, and B. Heymer, "Peripheral dentinogenic ghost cell tumor," Journal of Oral Pathology and Medicine, vol. 21, no. 2, pp. 93-95, 1992.

[20] W. H. Castro, M. C. Ferreira De Aguiar, and R. S. Gomez, "Peripheral dentinogenic ghost-cell tumor: a case report," Quintessence International, vol. 28, no. 1, pp. 45-47, 1997.

[21] G. Iezzi, C. Rubini, M. Fioroni, and A. Piattelli, "Peripheral dentinogenic ghost cell tumor of the gingiva," Journal of Periodontology, vol. 78, no. 8, pp. 1635-1638, 2007.

[22] C. Ledesma-Montes, R. J. Gorlin, M. Shear et al., "International collaborative study on ghost cell odontogenic tumours: calcifying cystic odontogenic tumour, dentinogenic ghost cell tumour and ghost cell odontogenic carcinoma," Journal of Oral Pathology and Medicine, vol. 37, no. 5, pp. 302-308, 2008.

[23] G. A. Candido, K. A. Viana, S. Watanabe, and E. F. Vencio, "Peripheral dentinogenic ghost cell tumor: a case report and review of the literature," Oral Surgery, Oral Medicine, Oral Pathology, Oral Radiology and Endodontology, vol. 108, no. 3, pp. e86-e90, 2009.

[24] S. P. Hong, G. L. Ellis, and K. S. Hartman, "Calcifying odontogenic cyst. A review of ninety-two cases with reevaluation of their nature as cysts or neoplasms, the nature of ghost cells, and subclassification," Oral Surgery Oral Medicine and Oral Pathology, vol. 72, no. 1, pp. 56-64, 1991.

[25] A. Buchner and L. S. Hansen, "The histomorphologic spectrum of the gingival cyst in the adult," Oral Surgery Oral Medicine and Oral Pathology, vol. 48, no. 6, pp. 532-539, 1979.

[26] M. Altini and A. G. Farman, "The calcifying odontogenic cyst. Eight new cases and a review of the literature," Oral Surgery Oral Medicine and Oral Pathology, vol. 40, no. 6, pp. 751-759, 1975.

[27] J. P. Sapp and D. G. Gardner, "An ultrastructural study of the calcifications in calcifying odontogenic cysts and odontomas," Oral Surgery Oral Medicine and Oral Pathology, vol. 44, no. 5, pp. 754-766, 1977.

[28] Y. Tajima, J. Ohno, and N. Utsumi, "The dentinogenic ghost cell tumor,” Journal of Oral Pathology, vol. 15, no. 6, pp. 359362, 1986.

[29] M. Juneja and J. George, "Dentinogenic ghost cell tumor: a case report and review of the literature," Oral Surgery, Oral Medicine, Oral Pathology, Oral Radiology and Endodontology, vol. 107, no. 5, pp. e17-e22, 2009.
[30] G. Sun, X. Huang, Q. Hu, X. Yang, and E. Tang, "The diagnosis and treatment of dentinogenic ghost cell tumor," International Journal of Oral and Maxillofacial Surgery, vol. 38, no. 11, pp. 1179-1183, 2009. 


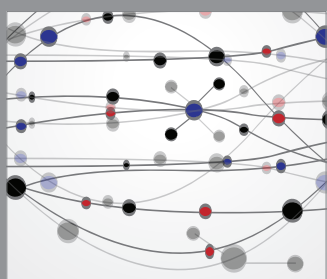

The Scientific World Journal
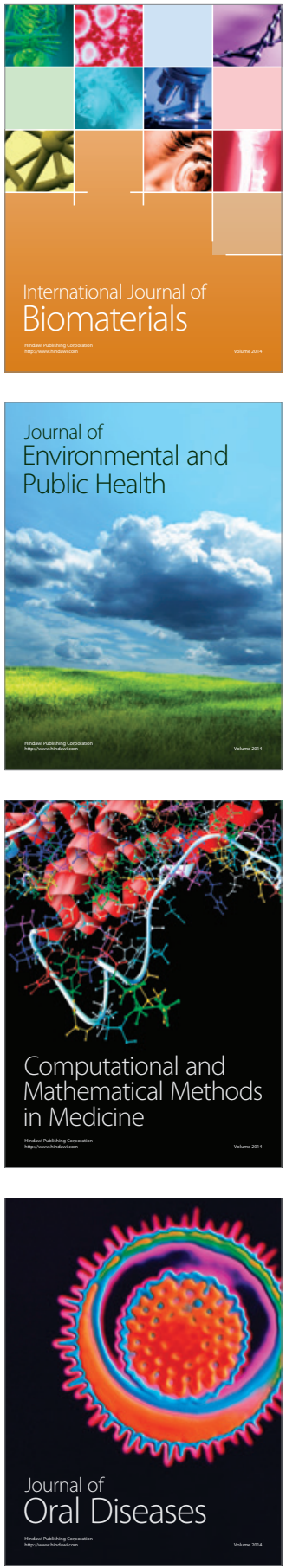
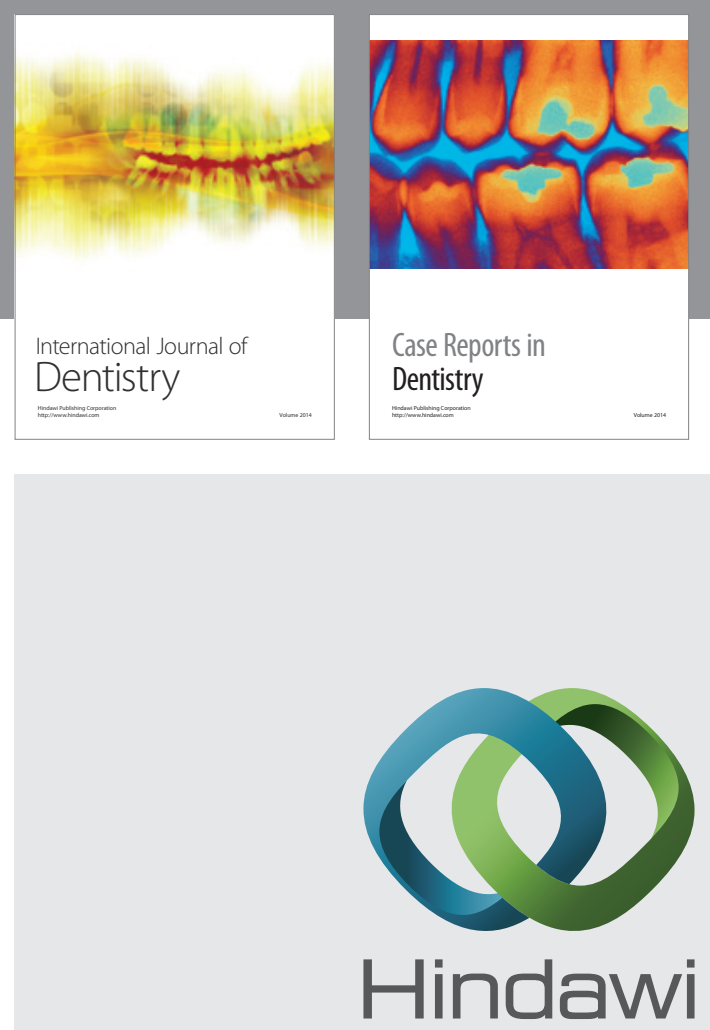

Submit your manuscripts at

http://www.hindawi.com
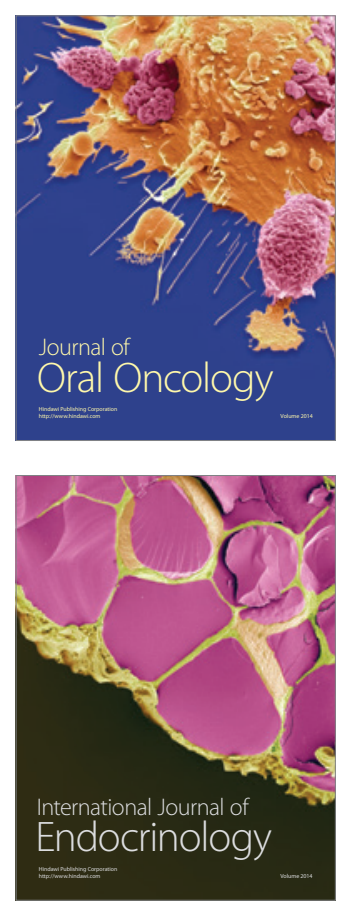
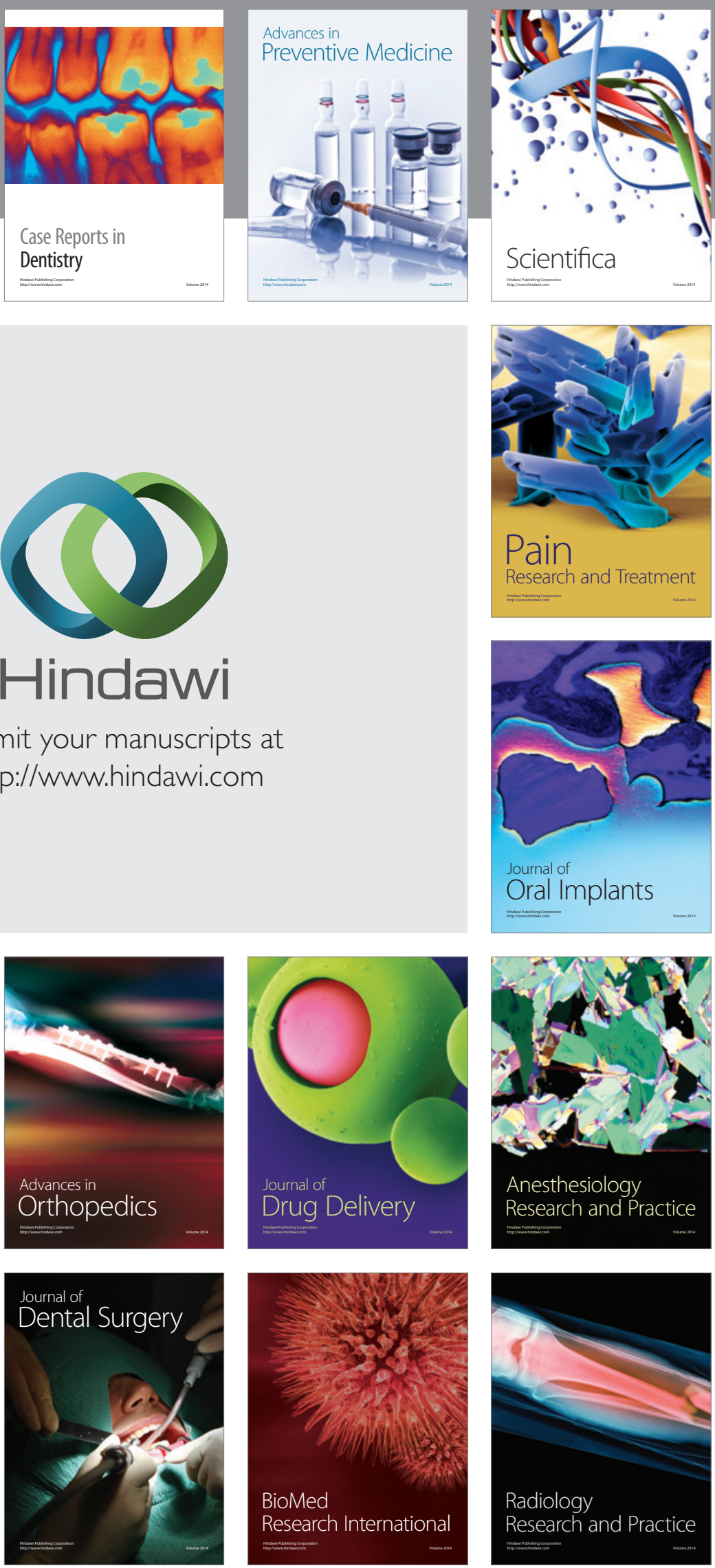